\title{
Influence of Diluted Seawater Irrigation on Seed Germination of Moringa oleifera, and Moringa Peregrina
}

\section{Sameera Bafeel, Aysha Alrashedi, Hameed Alsamadany, Abdualmonem A. Al Toukhy* Yahya Al Zahrani}

Department of Biological Sciences, King Abdulaziz University, Jeddah Saudi Arabia

Correspondence Author: Sameera Bafeel, Department of Biological Sciences, King Abdulaziz University, Jeddah Saudi Arabia

Received date: 23 January 2018, Accepted date: 27 March 2018, Online date: 10 April 2018

Copyright: (C) 2018 Sameera Bafeel et al. This is an open-access article distributed under the terms of the Creative Commons Attribution License, which permits unrestricted use, distribution, and reproduction in any medium, provided the original author and source are credited.

\begin{abstract}
Current study deals with the impact of irrigation with seawater during germination and seedling growth and to identify salinity tolerance in Moringa species that can be utilized for further physiological, chemical and genetic studies. The genus Moringa -following the family of Moringaceae, a fast-growing plant that has 13 species. In present study two Moringa species (Peregrina and Oleifera) were irrigated with six different levels of diluted Red seawater $(0,10 \%, 25 \%, 35 \%, 45 \%$ and $60 \%)$ that equal $(3500,8750,12250,15575$ and $21000 \mathrm{ppm}$ respectively) for evaluating g the effect of diluted Red seawater irrigation on germination percentage. The result of germination percentage in Moringa Peregrina showed that $64 \%$, 56\%, $48 \%, 40 \%, 32 \%$ and 0 respectively, where the result of germination percentage in Moringa Oleifera showed that $60 \%$, $48 \%$, $40 \%, 32 \%, 20 \%$ and 0 respectively. Therefore, germination rate decreases gradually with increased Red Seawater concentration. Also, germination in M. peregrina is faster than in M.oleifera two days.
\end{abstract}

Key words:

\section{INTRODUCTION}

The genus Moringa -following the family of Moringaceae, a fast-growing plant that has 13 species [1]. Moringa originated in the Indian subcontinent and then distributed into many different tropical and subtropical countries of the world including Saudi Arabia [2]. Moringa peregrine and M. Oleifera Lam are the most widely cultivated species, which are indigenous to south Asia and were introduced and became naturalized in other parts of the world because of multifarious use and medicinal properties as well as environmental importance [3]. Germination is usually the emergence of a plant contained within a seed that leads to the generation of seedling. In addition, it is a process of activation of metabolic activities of the seed that results in formation of radicle and plumule [4]. Both internal and external factors determine the germination of seed. The most prominent external causes comprise optimum temperature, water, oxygen and light or dark interval. Numerous plants need different factors for successful germination of seed. Mostly it is determined by type of seed variety, plants ecological conditions, and seed internal factors like dormancy [5].[6] reported the best results for germination \%, growth characters and some chemical and mineral under the lowest seawater ratios in Moringa oleifera[7].On the other hand the production and soil salinity estimation for Moringa sp. could be an important source for soil the management of soil salinity in shallow saline groundwater[8].

The uptake of water by seeds have a direct relation with incline in $\mathrm{NaCl}$ concentration [7]. Decrease in seed germination percentage was recorded by increasing the concentration of $\mathrm{NaCl}$ in all cultivars. Besides, abrupt application of saline water increases the Na+ content of germinated seeds that lead toward the diminishing of $\mathrm{K}+$ level as observed in Moringa cultivars by [9]. The main objective of current study is to interrogate the effect of different levels of Red seawater on the germination rate of two Moringa species (Olifera and Peregrine). It will be helpful in screening out the impact of increasing salinity levels on the germination tendency of both cultivars by making comparative evaluation.

\section{MATERIAL AND METHODS}

Germination test were carried out according method described by Mafton Sepaskhah (1978) for 21 days using six seawater levels (0, 10,25,35,45 and 60\%).

Five seeds of both species of Moringa (Olifera and Peregrine) were placed on absorbent pads in petri dishes. Afterward, 50 ml from different seawater concentration were added in five replicates for each. Seeds germination was considered after the radical emergence from the testa a of seeds. Germination percentages were recorded after every $24 \mathrm{~h}$ upto seven days. The whole experiment was conducted in RCBD using five replicates, while statistical analysis was conducted using Statistix 8.1 the means were compared using LSD ( $P \leq 0.05$; Steel et al., 1997). The Mean germination was calculated to assess the germination rate. According to the rules of the Association of Official Seed Analysts (AOSA 1990), the seed germination percentage was calculated using the following equation:

Germination percentage $=($ No.of. Germinated seeds $/$ Total seeds number $) \times 100$

Results:

The germination percentage recorded in Moringa peregrina was $64 \%, 56 \%, 48 \%, 40 \%, 32 \%$ and 0 , while the percentage recorded in Moringa oleifera was $60 \%, 48 \%, 40 \%, 32 \%, 20 \%$ and $0 \%$ under the supplementation of $0,10,25,35,45$ and $60 \%$ of saline water. Both, figure 1 and 2 are illustrating a corresponding decline in germination percentage with incline in the proportion of sea water. Among both cultivars the germination percentage recorded as zero at $60 \%$ seawater concentration. However, at zero concentration $M$. peregrine revealed the maximum germination $64 \%$ that was higher than the maximum percentage $60 \%$ of 
M.oleifera at the same concentration. It indicates the higher viability of the seeds of M.peregrina as compared to M.oleifera. Correspondingly for the same percentages of seawater higher decline in germination percentages was noticed in M.oleifera as compared to M. peregrina. It explicates the higher tolerance of $M$. peregrina to salinity during the phase of germination. Tables 1a and 1bare illustrating the ANOVA and comparison of means using LSD (P $\leq 0.05)$ respectively for M.peregrina. Significant impact of all salinity treatments on germination percentages was noticed during all days (table $1 \mathrm{~b}$ ). Corresponding results were noticed for M.Oleiferaas indicated in ANOVA and mean comparison tables (Table $2 a$ and table $2 b$ ) using LSD ( $P \leq 0.05)$. An overall comparison of table $1 b$ and table $2 b$ reveals more dynamic impact of salinity on the germination of M. oleifera as compared to M.peregrina.

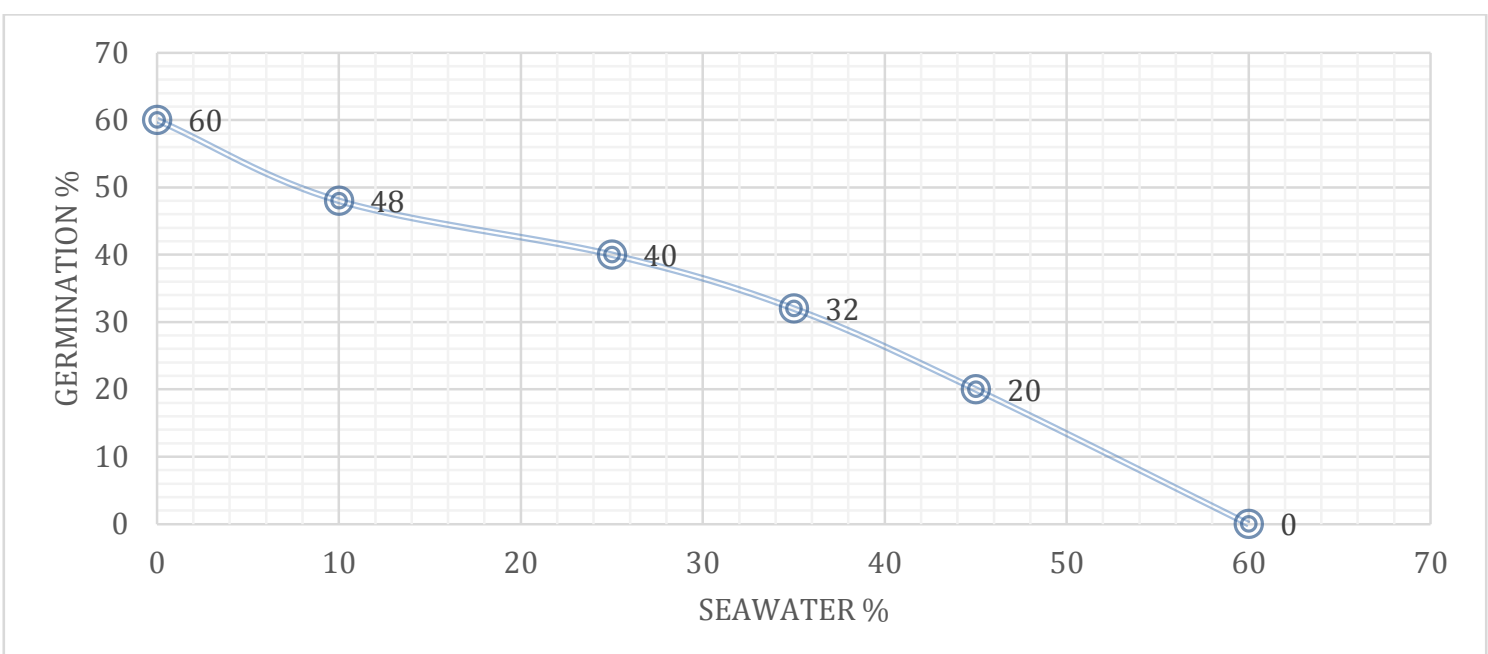

Fig. 1: Effect of diluted seawater irrigation on Moringa Peregrina, seed germination percentage.

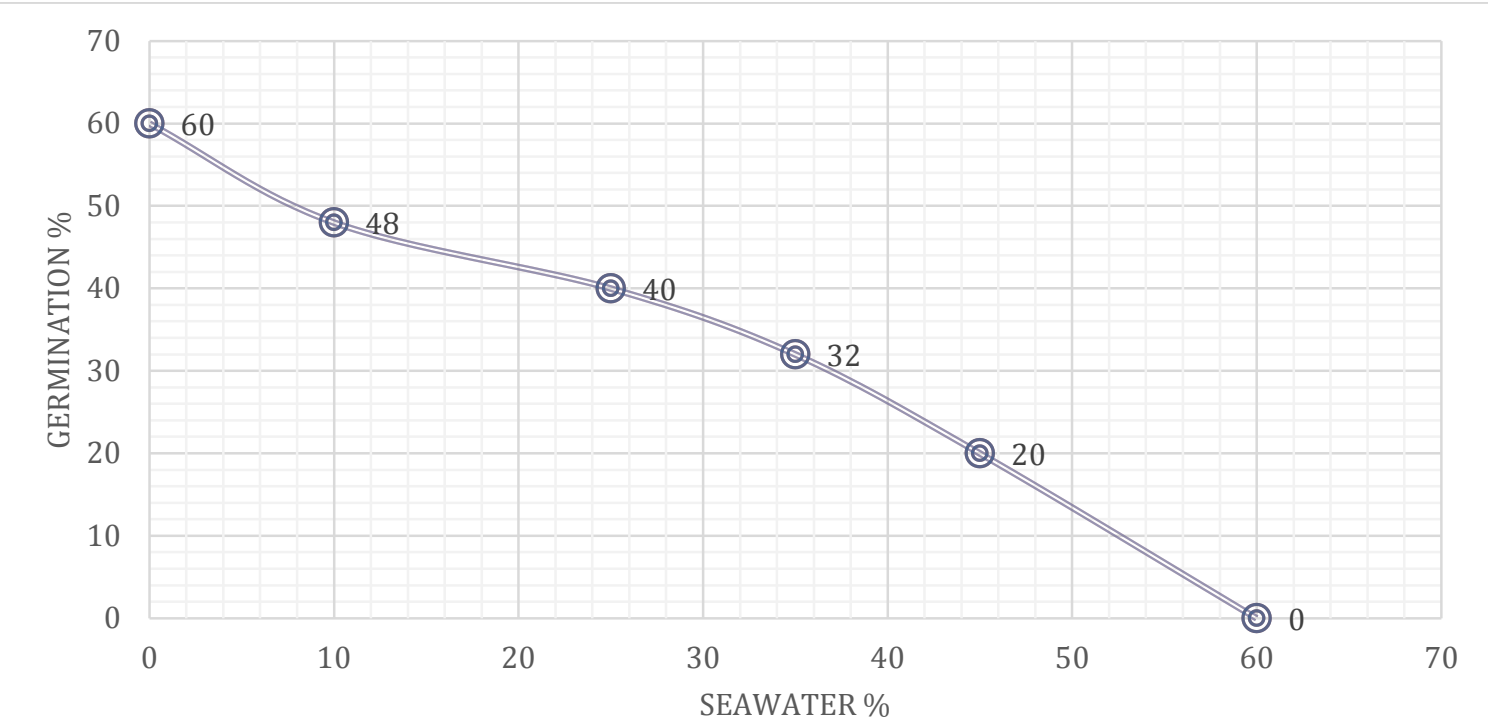

Fig. 2: Effect of diluted seawater irrigation on Moringa oleifera, seed germination percentage

Table 1a: Analysis of variance table for Moringa Peregrina.

\begin{tabular}{llllll}
\hline Source of variation & $\mathrm{df}$ & Day 4 & Day 5 & Day 6 & \\
\cline { 2 - 6 } & & MS & & $2.03 \mathrm{~ns}$ & Day 7 \\
\hline Replication & 4 & $0.78 \mathrm{~ns}$ & $2.21 \mathrm{~ns}$ & $3.38 \mathrm{~ns}$ & $7.10^{*}$ \\
Irrigations & 5 & $4.40^{*}$ & $5.01^{*}$ & $3.46 \mathrm{~ns}$ & $8.23^{*}$ \\
Error & 20 & 0.58 & 0.69 & 0.63 & 1.18 \\
total & 29 & & & \\
\hline
\end{tabular}

*, ** indicate significant differences at $0.05,0.01$ probability levels respectively while 'ns' indicate non-significant difference

Table 1b: Effect of sea water concentrations on germination percentage of Moringa Peregrina.

\begin{tabular}{|c|c|c|c|c|c|c|}
\hline $\begin{array}{l}\text { Salinity } \\
(\%)\end{array}$ & levels & 4 days germination & 5 days germination & 6 days germination & 7 days germination & 8 days germination \\
\hline 0 & & $2.4 \mathrm{a}^{*}$ & $2.4 \mathrm{a}$ & $2.4 \mathrm{a}$ & $2.4 \mathrm{a}$ & $3.13 \mathrm{a}$ \\
\hline 10 & & $1.2 \mathrm{~b}$ & $1.2 \mathrm{bc}$ & $1.8 \mathrm{ab}$ & $1.8 \mathrm{ab}$ & $2.9 \mathrm{ab}$ \\
\hline 25 & & $1 \mathrm{bc}$ & $1.6 \mathrm{ab}$ & $1.8 \mathrm{ab}$ & $1.8 \mathrm{ab}$ & $2.3 \mathrm{ab}$ \\
\hline 35 & & $0.2 \mathrm{bc}$ & $2.2 \mathrm{ab}$ & $2.6 \mathrm{a}$ & $2.6 \mathrm{a}$ & $3.1 \mathrm{a}$ \\
\hline 45 & & $0 \mathrm{c}$ & $0.2 \mathrm{~cd}$ & $1.2 \mathrm{~b}$ & $1.2 \mathrm{bc}$ & $1.35 \mathrm{bc}$ \\
\hline 60 & & $0 \mathrm{c}$ & $0 \mathrm{~d}$ & $0 \mathrm{c}$ & $0 \mathrm{c}$ & $0 \mathrm{c}$ \\
\hline LSD & & 0.65 & 0.68 & 0.59 & 0.63 & 0.67 \\
\hline
\end{tabular}

*Means followed by the same letter (s) in each column and treatment showed no significant difference 
Citation: Sameera Bafeel, AyshaAlrashedi, Abdualmonem A. AlToukhy, 2018. Influence of Diluted Seawater Irrigation on Seed Germination of Moringa oleifera, and Moringa Peregrina. Advances in Environmental Biology., 12(3): 10-12

Table 2: Analysis of variance table for Moringa oleifera.

\begin{tabular}{lllll}
\hline Source of variation & $\mathrm{df}$ & Day 5 & Day 6 & Day 7 \\
\cline { 2 - 5 } & & Ms & & \\
\hline Replication & 4 & $0.61 \mathrm{~ns}$ & $0.55 \mathrm{~ns}$ & $0.88 \mathrm{~ns}$ \\
Irrigations & 5 & $4.13^{*}$ & $5.04^{*}$ & $6.67^{*}$ \\
Error & 20 & 0.81 & 0.59 & 0.62 \\
total & 29 & & & $0.40 \mathrm{~ns}$ \\
\end{tabular}

*, ** indicate significant differences at $0.05,0.01$ probability levels respectively while 'ns' indicate non-significant difference

Table 1b: Effect of sea water concentrations on germination percentage of Moringa oleifera.

\begin{tabular}{|c|c|c|c|c|}
\hline Salinity levels (\%) & 5 days germination & 6 days germination & 7 days germination & 8 days germination \\
\hline 0 & $0.40 \mathrm{c}^{*}$ & $1.00 \mathrm{~b}$ & $2.60 \mathrm{a}$ & $3.40 \mathrm{a}$ \\
\hline 10 & $2.20 \mathrm{a}$ & $2.20 \mathrm{a}$ & $2.40 \mathrm{a}$ & $2.80 \mathrm{a}$ \\
\hline 25 & $1.80 \mathrm{ab}$ & $2.40 \mathrm{a}$ & $2.60 \mathrm{a}$ & $3.20 \mathrm{a}$ \\
\hline 35 & $1.80 \mathrm{ab}$ & $2.20 \mathrm{a}$ & $2.40 \mathrm{a}$ & $3.00 \mathrm{a}$ \\
\hline 45 & $0.60 \mathrm{bc}$ & $0.60 \mathrm{~b}$ & $0.60 \mathrm{~b}$ & $0.80 \mathrm{~b}$ \\
\hline 60 & $0.00 \mathrm{c}$ & $0.00 \mathrm{~b}$ & $0.00 \mathrm{~b}$ & $0.00 \mathrm{~b}$ \\
\hline LSD & 1.06 & 1.02 & 1.04 & 1.01 \\
\hline
\end{tabular}

*Means followed by the same letter (s) in each column and treatment showed no significant difference

\section{Discussion:}

The uptake of water by seeds got slow down with the increment in the level of salinity, therefore, both seed germination and root elongation are inhibited [7]. On the other hand under normal supply of water, the imbibition of seeds owe to hydration triggers the metabolic activities that breaks seed dormancy [10]. However, under salinity water has less potential gradient in soil and due to osmosis, it moves out from the seeds leading toward seed death [8]. Therefore, to move the water from soil into seed cells the water potential in soil should be higher than the water potential in seeds. Maximum water potential is arbitrarily attributed as zero to the distilled water that enables smooth water into the seed cells and increases the germination percentage upto 90\% in Moringa[11]. Moreover, [12] noticed analogous germination results seeds of Moringa under various salinity conditions. [6] found that lowest seawater ratios in Moringa oleifera irrigation water gave the best results for germination \%. Complementary results were observed in current study where we observed maximum germination percentage for both cultivars of Moringa at zero concentration of saline water. Besides, increased salinity concentrations decrease the rate of water uptake and enzymatic activation in addition to declined seed metabolism, testa rupture, and root emergence. This explains the low germination percentage rates in lower percent ( $0 \%$, $10 \%$ and $25 \%)$ seawater in the irrigation.

\section{REFERENCES}

[1] Fuglie, L.J., 1999. The Miracle Tree: Moringa oleifera: Natural Nutrition for the Tropics (p. 68). Church World Service, Dakar. Revised in 2001 and published as The Miracle Tree: The Multiple Attributes of Moringa, p: 172.

[2] Alaklabi, A., 2015. Genetic diversity of Moringa peregrina species in Saudi Arabia with ITS sequences. Journal of Horticulture and Forestry,7:36-47.doi: 10.1016/j.sjbs.2014.09.015.

[3] El-Alfy, T.S., S.M. Ezat, A.K. Hegazy, A.M.M. Amer, G.M. Kamel, 2011. Isolation of biologically active constituents from Moringa peregrina (Forsk.) Fiori (Family: Moringaceae) growing in Egypt. Pharmacognosy Magazine, 26: 109-115. doi: 10.4103/0973-1296.80667.

[4] Raven, Peter H., Ray F. Evert, Susan E. Eichhorn, 2005. Biology of Plants, 7th Edition. New York: W.H. Freeman and Company Publishers. pp. 504-508.

[5] Sadhu, M.K., 1989. Plant propagation. New Age International., p: 61.

[6] Hegazi, M.A., 2015. Influence of Soil Type, Sowing Date and Diluted Seawater Irrigation on Seed Germination, Vegetation and Chemical Constituents of Moringa oleifera, Lam. Journal of Agricultural Science., 7: 1916-9760.http://dx.doi.org/10.5539/jas.v7n3p138

[7] El-Dabh, R.S., M.A. El-Khateeb, A.A.M. Mazher and A.A. Abd El-Badaie, 2011. Effect of salinity on growth and chemical constituents of Moringa oleifera, Lam. Bull. Fac. Agric., Cairo Univ., 62(3): 261-386.

[8] Nouman, W., M.T. Siddiqui, S.M.A. Basra, R.A. Khan, T. Gull, M.E. Olson, H. Munir, 2012. Response of Moringa oleiferato saline conditions. International Journal of Agriculture and Biology, 14: 757-762.

[9] Anwar, F., A.I. Hussain, M. Ashraf, A. Jamail and S. Iqbal, 2006. Effect of salinity on yield and quality of Moringa oleifera seed oil. Grasas Y Aceites., 57(4): 394-401.

[10] Katembe, W.J., I.A. Ungar and J.P. Mitchell, 1998. Effect of Salinity on Germination and Seedling Growth of two Atriplex species (Chenopodiaceae).Annals of Botany, 82: 167-175.

[11] Taiz, L.and E. Zeiger, 2006. Plant Physiology.4th ed. Massachussets: Sinauer Associates, Inc., Publishers.

[12] Zaghloul, M.S., R.H. Abd El-Wahab, A.A. Moustafa, 2010. Ecological assessment and phenotypic and fitness variation of sinai's remnant populations of Moringa Peregrina. Applied Ecology and Environmental Research, 8: 351-366.

[13] AOSA., 1990. Rules for testing seeds. J. Seed Technol., 12, 1-112. Association of Official Analytical Chemist (AOAC). (1990). Protein (Crude) determination in Animal Feed: Copper Catalyst Kjeldahl Method. Official Methods of Analysis (15th ed., pp. 992-995). Washington DC.

[14] Steel, R.G.D., J.H. Torrie, D.A. Dicky, 1997. Principles and Procedures of Statistics-A Biometrical Approach. Mc Graw-Hill, New York, NY. 